\title{
Hypersensitive response, cell death and histochemical localisation of hydrogen peroxide in host and non-host seedlings infected with the downy mildew pathogen Sclerospora graminicola
}

\author{
By B S KUMUDINI, N S VASANTHI and H S SHETTY* \\ Downy Mildew Research Laboratory, Department of Applied Botany and Biotechnology \\ University of Mysore, Mysore - 570 006, Karnataka, India
}

(Accepted 25 June 2001; Received 2 May 2000)

\begin{abstract}
Summary
Hypersensitive response, cell death and release of hydrogen peroxide as measures of host and nonhost defense mechanisms upon inoculation with the downy mildew pathogen Sclerospora graminicola were studied histochemically at the light microscopy level. The materials consisted of coleoptile tissues of the highly susceptible (cv. HB3), highly resistant (cv. IP18293) and induced resistant pearl millet host seedlings and non-host sorghum (cv. SGMN 10/8) and cotyledon of french bean (cv. S9). Resistance up to $80 \%$ protection against the downy mildew pathogen was induced in the highly susceptible HB3 cultivar of pearl millet by treating the seeds with $2 \%$ aqueous leaf extract of Datura metel for $3 \mathrm{~h}$. Time course study with the pathogen inoculated highly resistant pearl millet cultivar revealed the appearance of hypersensitive response in $20 \%$ of seedlings as necrotic spots as early as $2 \mathrm{~h}$ after inoculation. In contrast, a similar reaction was observed in the highly susceptible pearl millet cultivar only $8 \mathrm{~h}$ after inoculation with the pathogen. In induced resistant seedlings, appearance of hypersensitive response was recorded $4 \mathrm{~h}$ after inoculation. Delayed hypersensitive response was observed in both the non-host species at $10 \mathrm{~h}$ after inoculation. Hypersensitive response in the seedlings of the highly resistant pearl millet cultivar $24 \mathrm{~h}$ after inoculation showed 100\% hypersensitive response, which was not observed in susceptible and non-host species, although the induced resistant seedlings showed $90 \%$ hypersensitive response after that period of time. Cell death in the tissues of the test seedlings was also observed to change with time. Statistical analysis revealed that the tissues of highly resistant pearl millet seedlings required $2.9 \mathrm{~h}$ to attain $50 \%$ cell death. Tissues of induced resistant and highly susceptible pearl millet seedlings required 4.65 and $6.50 \mathrm{~h}$ respectively. In non-hosts, $50 \%$ cell death was not recorded. Quantification of hydrogen peroxide in the tissue periplasmic spaces of the test seedlings revealed $2.94 \mathrm{~h}$ as the time required for $50 \%$ hydrogen peroxide accumulation in the tissues of highly resistant pearl millet seedlings. Tissues of induced resistant and highly susceptible pearl millet seedlings needed 3.76 and $5.5 \mathrm{~h}$ respectively. Fifty percent hydrogen peroxide localisation in non-hosts could not be recorded. These results suggested the involvement of hydrogen peroxide, cell death and hypersensitive response in pearl millet host defense against $S$. graminicola.
\end{abstract}

Key words: Sclerospora graminicola, pearl millet, non-host, defence response, localisation of hydrogen peroxide, cell death, hypersensitive response

\section{Introduction}

In nature, plants are exposed to different pathogens and in response to their attack they show a variety of defense mechanisms either to strengthen their resistance or to weaken the pathogen (Milosevic \& Slusarenko, 1996; Thordal-Christensen et al., 1997; Bestwick et al., 1997; Huckelhoven et al., 1999). Oxidative burst leading to the production of active oxygen species (AOS) is one of the earliest and immediate defense responses to pathogen attack and/ or elicitor treatment (Lamb \& Dixon, 1997; MartyTeysset et al., 2000). AOS include superoxide anion, hydroxyl radical and hydrogen peroxide. Hydrogen peroxide $\left(\mathrm{H}_{2} \mathrm{O}_{2}\right)$, which is the stable compound formed by the splitting of superoxide anion during oxidative burst, has been hypothesised to play a number of roles in defense by participating in membrane damage, structural defense, bio-chemical signalling processes and as an antimicrobial compound (Tenhaken et al., 1995). It has also been documented that $\mathrm{H}_{2} \mathrm{O}_{2}$ accumulation can initiate programmed cell death leading to hypersensitive response (HR) resulting in the limited spread of the pathogen (Greenberg, 1997; Harding \& Roberts, 1998). AOS have been correlated with HR and cell death in many host-pathogen interactions (Rusterucci et al., 1996; Bestwick et al., 1997, 
Thordal-Christensen et al., 1997; Schulze-Lefert \& Vogel, 2000) and also in plants induced for resistance (Tenhaken et al., 1995; Heath, 1999; Huckelhoven et al., 1999).

In pearl millet-downy mildew interaction, HR has been observed as one of the immediate and rapidly occurring defence responses of genetically resistant pearl millet [Pennisetum glaucum (L.) R. Br.] cultivars upon inoculation with the downy mildew pathogen Sclerospora graminicola (Sacc.) Schroet. (Nagarathna et al., 1993). Cell necrosis as a defense reaction was also shown in this host-pathogen system using the elicitor, arachidonic acid (Geetha et al., 1998). Probably, these mechanisms also operate during resistance induction in pearl millet against downy mildew disease reported from the laboratory (Kumar et al., 1993, 1998; Shailasree et al., 2001). Hence, $\mathrm{H}_{2} \mathrm{O}_{2}$ localisation in the tissues of seedlings of host (pearl millet) and non-hosts (sorghum and french bean) of the downy mildew fungus $S$. graminicola was studied to correlate cell death and HR with host resistance.

\section{Materials and Methods}

\section{Host}

Pearl millet cultivars highly susceptible (HB3) and highly resistant (IP18293) to Sclerospora graminicola, obtained from the International Crops Research Institute for Semi-Arid Tropics (ICRISAT), Hyderabad, India, were used in the study. Non-host species used were sorghum [Sorghum bicolor (L.) Moench.] cv. SGMN 10/8 and french bean [Phaseolus vulgaris (L.)] cv. S9.

\section{Pathogen}

A virulent pathotype of $S$. graminicola, isolated from the highly susceptible HB3 cultivar of pearl millet and maintained on the same cultivar under green house conditions (Safeeulla, 1976), was used.

\section{Induction of resistance}

Resistance was induced by treating the seeds of the highly susceptible pearl millet cultivar HB3 with $2 \%$ aqueous leaf extract of Datura metel for $3 \mathrm{~h}$ at $25 \pm 2{ }^{\circ} \mathrm{C}$. The leaf extract was prepared by grinding $2 \mathrm{~g}$ fresh leaves in $100 \mathrm{ml}$ of distilled water. The seeds were treated $(100$ seeds in $20 \mathrm{ml})$ with the filtered and centrifuged (10000 rpm for $15 \mathrm{~min}$ ) extract (Shivakumar, 2000). Seeds of highly susceptible and highly resistant pearl millet and nonhosts treated to sterile distilled water served as controls. After the incubation period, the seeds were blotted dry and incubated in plates for germination at $25 \pm 2^{\circ} \mathrm{C}$.

\section{Inoculation}

Two-day-old seedlings of all test plants were inoculated with S. graminicola zoospore suspension prepared in sterile distilled water at the concentration of $4 \times 10^{4} \mathrm{ml}^{-1}$ such that $75 \%$ regions of the seedlings were covered during treatment (Safeeulla, 1976). Seedlings treated with sterile distilled water served as uninoculated controls.

\section{Downy mildew disease assessment}

One set of inoculated and uninoculated seedlings was transplanted to earthen pots of $12-15 \mathrm{~cm}$ diameter containing red soil, sand and manure in the ratio 2:1:1. Each pot containing 15-20 seedlings was irrigated and maintained under green house conditions at $25-30^{\circ} \mathrm{C}$ and $>95 \%$ r.h. for disease development (Safeeulla, 1976). Plants were observed daily for 30 days and rated as diseased when they showed any of the typical downy mildew symptoms like yellowing or reddish brown coloration, downy growth of the pathogen on the under surface of leaf, stunted growth and malformed earhead. At the end of 30 days, disease incidence was recorded as the percentage of plants showing downy mildew symptoms. The experiment was repeated three times with 100 seedlings for each cultivar and treatment.

\section{Observation for $H R$}

A second set of test seedlings was used to study the HR. Two-day-old test seedlings germinated on sterile blotters were inoculated by placing them in 9 $\mathrm{cm}$ diameter Petri plates (10 seedlings per plate) containing $15 \mathrm{ml}$ of $S$. graminicola zoospore suspension at a concentration of $4 \times 10^{4} \mathrm{ml}^{-1}$ under dark at $30^{\circ} \mathrm{C}$. The inoculated seedlings were observed at hourly intervals for the external appearance of necrotic spots/streaks on the coleoptile, root, and cotyledon regions. The initial time of appearance of HR and the number of seedlings showing the necrotic spots during the experimental period of $24 \mathrm{~h}$ were recorded and the percentage calculated. The experiment was repeated three times with two replicates each containing 10 seedlings.

\section{Sampling of the seedlings for microscopic study}

For time-course study, test seedlings were sampled at two hour intervals for $24 \mathrm{~h}$ after inoculation with S. graminicola as described for HR. Peelings of test seedling coleoptiles with and without the external appearance of necrotic spots were used for light microscopic analysis for cell death and localisation of $\mathrm{H}_{2} \mathrm{O}_{2}$. For french bean, peelings from cotyledon were used.

\section{Evaluation of host cell death}

Host cell death was observed both at the region with and without external necrotic spots in the tissues of the test seedlings following neutral red staining 
(O’Connell et al., 1985). Thin strips of epidermal peelings were immersed in a solution of $0.2 \%$ neutral red stain prepared by dissolving the stain in $0.1 \mathrm{M}$ potassium phosphate buffer $(\mathrm{pH} 7.6)$ containing 0.5 $\mathrm{M}$ sucrose. The stained cells viable after $10 \mathrm{~min}$ treatment showed plasmolysis while dead cells appeared light yellow without plasmolysis. Twenty five random microscopic fields were observed for each of the samples to calculate percentage cell death.

\section{Localisation of $\mathrm{H}_{2} \mathrm{O}_{2}$}

$\mathrm{H}_{2} \mathrm{O}_{2}$ was localised in the tissues described above following the method of Olson \& Varner (1993). The peelings were placed in freshly prepared aqueous solution of $50 \mathrm{mM}$ potassium iodide in $4 \%$ aqueous solution of soluble starch. After incubation for 45 min, the epidermal peelings were mounted in $10 \%$ glycerol and observed under the microscope. $\mathrm{H}_{2} \mathrm{O}_{2}$ was localised due to dark blue coloration in the periplasmic space of the cells. The number of cells with $\mathrm{H}_{2} \mathrm{O}_{2}$ in 20 random microscopic fields were counted and percentage calculated.

Quantification of $\mathrm{H}_{2} \mathrm{O}_{2}$ was also evaluated by developing a five-point scale where the localisation was classified into the following categories: $0-$ no localisation; 1 - light and patchy; 2 - light and confluent; 3 - dark and patchy; 4 - dark and confluent deposits (Bestwick et al., 1997).

\section{Statistical analyses}

Data on downy mildew disease incidence were subjected to Duncan's multiple range test (DMRT) and the level of significance compared at $5 \%$. A Gompertz curve equation was applied to determine the time required for $50 \% \mathrm{HR}$, cell death and $\mathrm{H}_{2} \mathrm{O}_{2}$ localisation. Chi-squared test was applied for $\mathrm{H}_{2}^{2} \mathrm{O}_{2}$ quantification in response to time after inoculation with the pathogen.

\section{Results}

\section{Downy mildew disease assessment}

Screening of pearl millet cultivars, sorghum and french bean under greenhouse conditions showed varying downy mildew incidence ranging from 495\% disease (Table 1). All infected pearl millet cultivars showed any one or more of the typical downy mildew disease symptoms. Pearl millet cultivar IP18293 that recorded only 4\% of disease incidence was rated as highly resistant to downy mildew disease. HB3 cultivar of pearl millet was rated as highly susceptible since it recorded $95 \%$ disease incidence. Seedlings raised from HB3 seeds induced for resistance with $2 \%$ aqueous leaf extract of Datura metel recorded only 20\% disease. Hence, such plants were considered resistant to downy mildew. Both the non-hosts, sorghum and french bean, did not show any of the downy mildew disease symptoms and thus recorded $0 \%$ disease incidence.

\section{Hypersensitive response}

Reaction of the test seedlings to Sclerospora graminicola upon inoculation under laboratory

Table1. Relationship between downy mildew disease incidence (DMDI), hypersensitive response (HR), cell death and localisation of hydrogen peroxide $\left(\mathrm{H}_{2} \mathrm{O}_{2}\right)$ in seedlings of pearl millet, sorghum and french bean as a response to inoculation with Sclerospora graminicola

\begin{tabular}{|c|c|c|c|c|c|}
\hline \multirow[b]{4}{*}{ Test seedling } & \multirow{4}{*}{$\begin{array}{l}\text { Greenhouse } \\
\text { screening* } \\
\text { DMDI }^{1} \%\end{array}$} & \multicolumn{4}{|c|}{ Response to Sclerospora graminicola } \\
\hline & & \multicolumn{4}{|c|}{ Laboratory screening** } \\
\hline & & \multirow{2}{*}{$\begin{array}{l}\text { Initial time of } \mathrm{HR} \\
\text { appearance }^{1} \text { (hai) }\end{array}$} & \multirow{2}{*}{$\begin{array}{c}\% \text { seedlings with } \\
\mathrm{HR}^{1} \text { at } 24 \text { hai }\end{array}$} & \multicolumn{2}{|c|}{ Time required (h) for $50 \%^{2}$} \\
\hline & & & & Cell death*** & $\mathrm{H}_{2} \mathrm{O}_{2}$ localisation*** \\
\hline $\begin{array}{l}\text { Highly resistant pearl millet } \\
\text { (IP18293) - Host }\end{array}$ & $4^{\mathrm{a}}$ & $2^{\mathrm{a}}$ & $100^{\mathrm{a}}$ & 2.94 & 2.90 \\
\hline $\begin{array}{l}\text { Induced resistant pearl millet } \\
\text { (HB3 treated with } 2 \% \text { leaf } \\
\text { extract of Datura metel) - Host }\end{array}$ & $20^{\mathrm{b}}$ & $4^{\mathrm{a}}$ & $90^{\mathrm{a}}$ & 4.65 & 3.76 \\
\hline $\begin{array}{l}\text { Highly susceptible Pearl Millet } \\
\text { (HB3) - Host }\end{array}$ & $95^{\mathrm{c}}$ & $8^{c}$ & $75^{\mathrm{c}}$ & 6.50 & 5.57 \\
\hline $\begin{array}{l}\text { Sorghum (cv. SGMN 10/8) - } \\
\text { Non-host }\end{array}$ & 0 & $10^{\mathrm{c}}$ & $47^{\mathrm{d}}$ & 0.00 & 0.00 \\
\hline French bean (cv. S9) - Non-host & 0 & $10^{\mathrm{c}}$ & $42^{\mathrm{d}}$ & 0.00 & 0.00 \\
\hline
\end{tabular}

*Average of three independent experiments with 100 seedlings each.

** Average of three independent experiments each with two replicates of 10 seedlings.

$* * *$ Values indicate the time required for $50 \%$ cell death $/ \mathrm{H}_{2} \mathrm{O}$, localisation at the region of $\mathrm{HR}$.

1 Values followed by the same letters of the alphabet in each column are not significantly different from each other according to DMRT analysis.

${ }^{2}$ Values are the results of the time required for $50 \%$ cell death and $\mathrm{H}_{2} \mathrm{O}_{2}$ localisation as per Gompertz curve equation; hai - hours after inoculation. 
conditions was observed as hypersensitive necrosis in the form of brown necrotic spots or streaks in different parts of the test seedlings. The time-course experiment conducted over a period of $24 \mathrm{~h}$ after inoculation with $S$. graminicola showed differences in the rapidity and percentage of seedlings showing the reaction by the different test seedlings (Fig. 1; Table 1). The spots that appeared light brown initially turned darker with increase in time after inoculation. The intensity and rapidity was more in the highly resistant and induced resistant seedlings. In the highly resistant pearl millet cultivar, HR appeared as early as $2 \mathrm{~h}$ after inoculation, with $20 \%$ of seedlings showing necrotic spots and increased to the maximum of $100 \%$ at $12 \mathrm{~h}$ of inoculation. In the induced resistant seedlings raised from HB3 seeds treated with $2 \%$ aqueous extract of $D$. metel, HR appeared by $4 \mathrm{~h}$, when $30 \%$ of the seedlings showed HR, and by 12 and $24 \mathrm{~h}$ it increased to 77 and $90 \%$ respectively. In the highly susceptible pearl millet seedlings, initial appearance of HR was delayed to $8 \mathrm{~h}$. Maximum HR of $75 \%$ was observed at $24 \mathrm{~h}$ while at $12 \mathrm{~h}$ only $54 \%$ seedlings showed HR. The non-host seedlings, sorghum and french bean, showed delayed and lowest percentage of HR throughout the test period. Initial necrosis was observed as late as $10 \mathrm{~h}$ after inoculation in $12 \%$ and $10 \%$ of sorghum and french bean respectively, while at $12 \mathrm{~h}, 22 \%$ and $18 \%$ of sorghum and french bean seedlings showed HR. At the end of the experiment period $(24 \mathrm{~h})$, the percentage increased to $47 \%$ and $42 \%$ respectively.

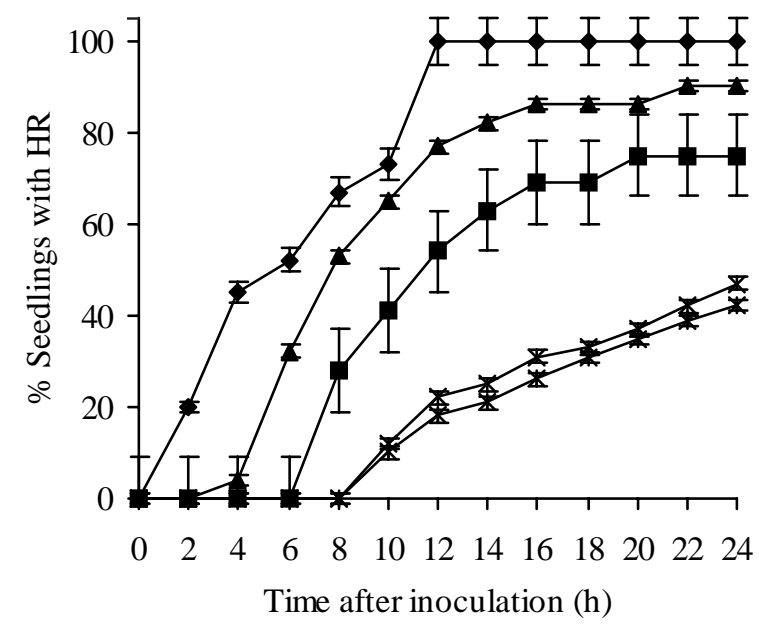

Fig. 1. Hypersensitive response in highly resistant (IP18293, $\bullet$ ), susceptible (HB3, 口) and induced resistant $(\mathrm{HB} 3+\mathrm{Dm}, \boldsymbol{\Delta})$ pearl millet and the non-hosts sorghum $(\mathrm{So}, \times)$ and french bean $(\mathrm{Fb}, *)$ on inoculation with Sclerospora graminicola. Vertical bars represent standard error. Dm - Datura metel.

\section{Cell death}

Cell death, one of the major resistant reactions as a response to inoculation with $S$. graminicola was assessed in the tissues of the coleoptile of the seedlings of pearl millet, sorghum and cotyledon of french bean. The epidermal peelings taken from the tissues with and without HR were stained with neutral red solution containing $0.5 \mathrm{M}$ sucrose. Living cells in the hypertonic solution attained plasmolysis and were darkly stained whereas the dead cells did not plasmolyse. Appearance of cell death as a factor of time is shown in Fig. 2. It was observed that 2\% of cells in the highly resistant pearl millet seedlings showed initial cell death as early as $2 \mathrm{~h}$ whereas in the highly susceptible and induced resistant seedlings cell death was recorded only after $4 \mathrm{~h}$. After $4 \mathrm{~h}, 4 \%$ death was observed in induced resistant seedlings while only $1 \%$ was recorded in the highly susceptible seedlings. At this time period, non-host sorghum and french bean seedlings showed delayed and reduced percentage of cell death $(2 \%$ and $1 \%$
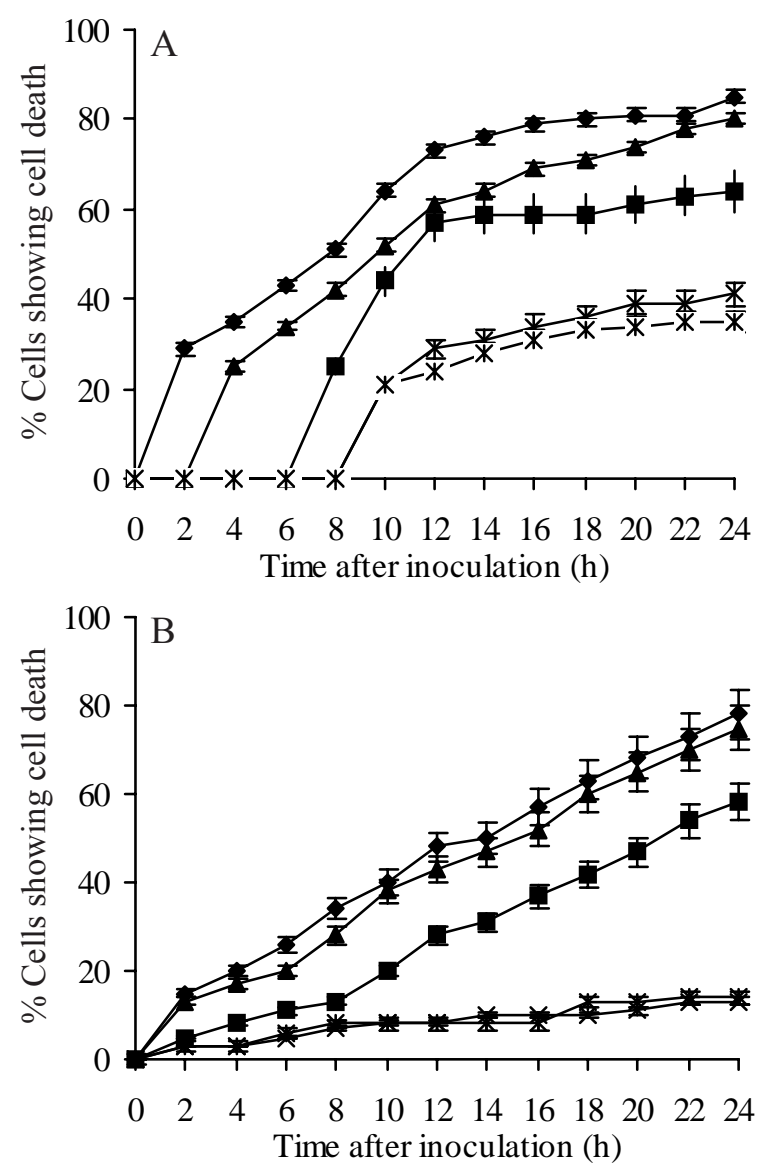

Fig. 2. Cell death in highly resistant (IP18293, $\bullet$ ), susceptible (HB3, $\mathbf{\square})$ and induced resistant $(\mathrm{HB} 3+\mathrm{Dm}$, $\Delta)$ pearl millet and the non-hosts sorghum (So, $x$ ) and french bean $(\mathrm{Fb}, *)$ on inoculation with Sclerospora graminicola in region with (A) and without (B) necrotic spots. Vertical bars represent standard error. Dm Datura metel. 
respectively). With increase in time, cell death numbers varied according to the different test seedlings. At $12 \mathrm{~h}$ of inoculation, a maximum of $29 \%$ was observed in the highly resistant pearl millet tissues and $23 \%, 14 \%, 11 \%$ and $11 \%$ in induced resistant pearl millet, highly susceptible pearl millet, sorghum and french bean tissues respectively. Though the percentage of cell death recorded by all the test seedlings increased with further incubation, after $24 \mathrm{~h}$ of inoculation, higher percentage of $37 \%$ and $33 \%$ was recorded in the highly resistant and induced resistant pearl millet tissues. In highly susceptible tissues, only $24 \%$ cell death was recorded after $24 \mathrm{~h}$ (Fig. 2).

To evaluate the percentage of cell death in different test seedlings statistically, Gompertz curve equation was applied and the time required to achieve 50\% cell death was calculated. In the region with HR, the highly resistant pearl millet seedlings required $2.90 \mathrm{~h}$ to attain $50 \%$ cell death which was more rapid than the $6.50 \mathrm{~h}$ in highly susceptible seedlings. Induced resistant pearl millet seedlings required 4.65 $\mathrm{h}$, while in non-host cultivars $50 \%$ cell death could not be obtained.

In the region without $\mathrm{HR}$, the highly resistant pearl millet seedlings needed $6.49 \mathrm{~h}$ to attain $50 \%$ cell death whereas the highly susceptible tissues needed $10.35 \mathrm{~h}$. Induced resistant seedlings needed $7.25 \mathrm{~h}$.

\section{Localisation of $\mathrm{H}_{2} \mathrm{O}_{2}$}

$\mathrm{H}_{2} \mathrm{O}_{2}$ was first observed as early as $30 \mathrm{~min}$ in all pearl millet seedlings, but to a varying extent and the response increased with time (Fig. 3). However, percent of $\mathrm{H}_{2} \mathrm{O}_{2}$ localised cells was highest in the highly resistant, followed by induced resistant and highly susceptible pearl millet seedlings at any point of study. It was observed that the highly resistant cultivar showed maximum $\mathrm{H}_{2} \mathrm{O}_{2}$ localisation of $91 \%$ at $24 \mathrm{~h}$, whereas the highly susceptible seedlings showed $75 \%$ of localisation at the end of $24 \mathrm{~h}$ (Fig. 3). Induced resistant seedlings showed $82 \% \mathrm{H}_{2} \mathrm{O}_{2}$ localisation at the end of $24 \mathrm{~h}$ while sorghum and french bean showed $53 \%$ and $56 \%$ respectively. When the above observation was statistically analysed by applying Gompertz curve equation and time required for $50 \%$ localisation calculated, it was observed that highly resistant tissues required 2.94 $\mathrm{h}$ for $50 \%$ localisation whereas the highly susceptible required $5.50 \mathrm{~h}$. Induced resistant seedlings needed $3.76 \mathrm{~h}$ while sorghum and french bean remained constant since $50 \% \mathrm{H}_{2} \mathrm{O}_{2}$ localisation in the region with necrotic spots was not observed (Table 1). In the region without necrotic spots, the highly resistant cultivar required $4.29 \mathrm{~h}$ for $50 \%$ of cells to be localised, whereas the highly susceptible cultivar required $7.55 \mathrm{~h}$. In the induced resistant tissues, localisation of $\mathrm{H}_{2} \mathrm{O}_{2}$ was more rapid than the highly susceptible as it required $4.96 \mathrm{~h}$.
Quantitative analysis of $\mathrm{H}_{2} \mathrm{O}_{2}$ localisation

$\mathrm{H}_{2} \mathrm{O}_{2}$ accumulation was objectively evaluated as a factor of time after inoculation with the pathogen by developing a five-point scale to assess the appearance of deposits of starch-iodine complex within the periplasmic space of the tissues of the test seedlings. They were classified into the following categories viz., 0 - no localisation; 1 - light and patchy; 2 - light and confluent; 3 - dark and patchy and 4 - dark and confluent deposits (Fig. 4). Localisation of $\mathrm{H}_{2} \mathrm{O}_{2}$ was observed in all the test seedlings but to varying degrees (Table 2). The quantitative study was carried out in the tissues of the test seedlings both with and without HR. At an initial time of $4 \mathrm{~h}$ after inoculation, more of the lightly coloured cells were observed than the other categories $(25 \%$ in highly resistant, $15 \%$ in induced resistant). In the highly susceptible pearl millet and non-host seedlings no visible HR was observed at that time and thus no data on localisation of the HR regions. In the region without $\mathrm{HR}, 27 \%, 25 \%$ and
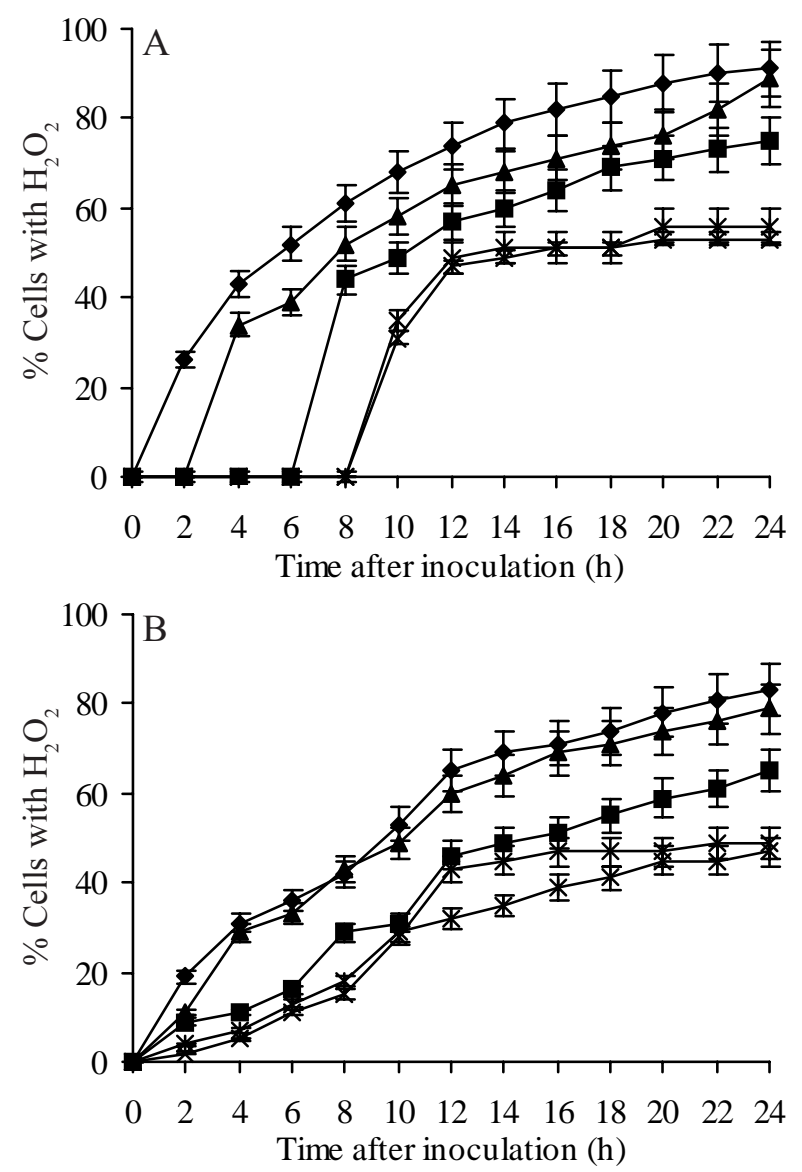

Fig. 3. Localisation of hydrogen peroxide $\left(\mathrm{H}_{2} \mathrm{O}_{2}\right)$ in highly resistant (IP18293, $\bullet$ ), susceptible ( $\left.\mathrm{HB}^{2}, \mathbf{D}\right)$ and induced resistant $(\mathrm{HB} 3+\mathrm{Dm}, \mathbf{\Delta})$ pearl millet and the non-hosts sorghum $(\mathrm{So}, \times)$ and french bean $(\mathrm{Fb}, *)$ on inoculation with Sclerospora graminicola in region with (A) and without (B) necrotic spots. Vertical bars represent standard error. Dm - Datura metel. 

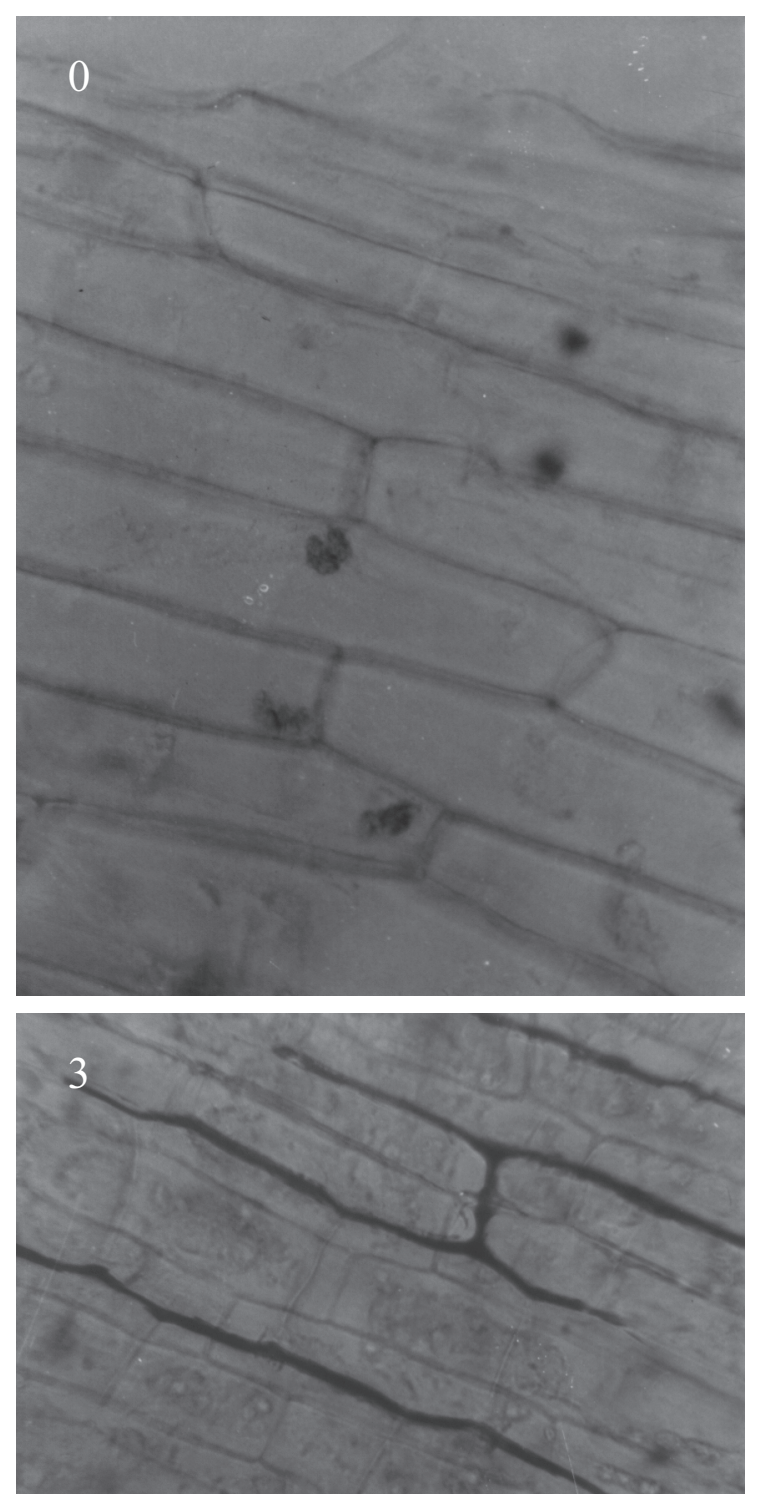
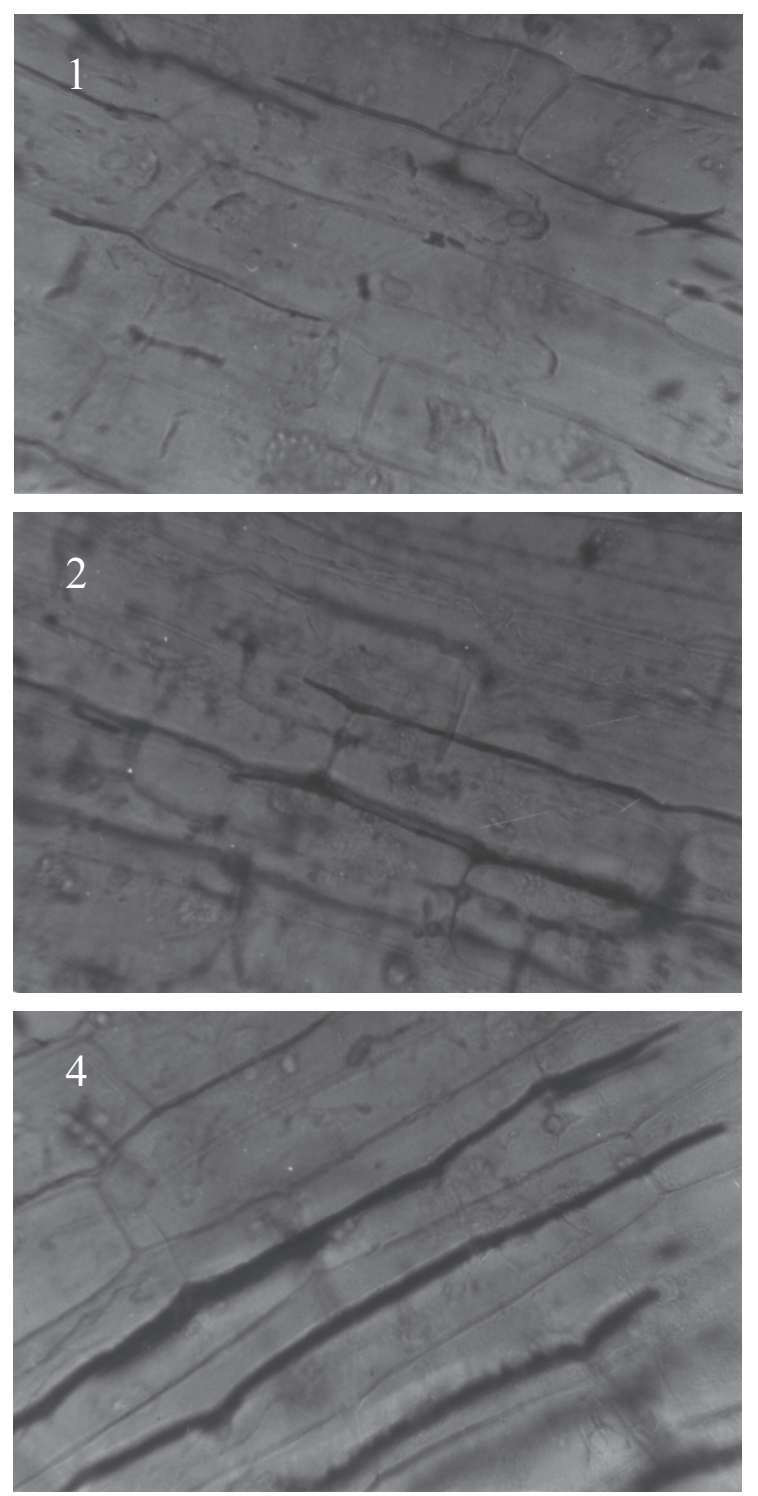

Fig. 4. Quantitative localisation of hydrogen peroxide in tissues of induced resistant pearl millet ( 0 - no localisation; 1 - light and patchy; 2 - light and confluent; 3 - dark and patchy; 4 - dark and confluent localisation) on inoculation with Sclerospora graminicola.

$11 \%$ of cells in highly resistant, induced resistant and highly susceptible pearl millet showed lightly localised cells. At the same time point, only 5\% and $7 \%$ of cells in sorghum and french bean recorded lightly localised cells. The darkly localised cells increased when observations were made with seedlings after $24 \mathrm{~h}$ after inoculation. In the region with $\mathrm{HR}, 91 \%, 74 \%$ and $53 \%$ of cells with darkly localised $\mathrm{H}_{2} \mathrm{O}_{2}$ were detected in the tissues of the resistant, induced resistant and susceptible seedlings. On the other hand, sorghum and french bean recorded $43 \%$ and $25 \%$ of cells respectively. In the region without HR, $13 \%, 11 \%$ and $9 \%$ of cells in highly resistant, induced resistant and susceptible showed dark confluent deposits of $\mathrm{H}_{2} \mathrm{O}_{2}$ while $11 \%$ and $8 \%$ were recorded in sorghum and french bean respectively. Chi-squared test was applied and the significance calculated at the 5\% level. From this test it was found that at each time point, the resistance parameter was dependent on the degree of $\mathrm{H}_{2} \mathrm{O}_{2}$ localisation.

\section{Discussion}

Disease reactions of host and the non-host cultivars under green house conditions upon inoculation with the downy mildew pathogen confirmed that pearl millet cultivar HB3 was highly susceptible and the cultivar IP18293 highly resistant to $S$. graminicola. Singh \& Prithviraj (1997), Wilson et al., (1997) and Konstantinidou-Deltsinis \& Schmitt (1998) have shown induction of resistance in plants against a number of pathogens using a variety of plant extracts. Experiments of the present study describing downy 
Table 2. Quantitative assessment of hydrogen peroxide $\left(\mathrm{H}_{2} \mathrm{O}_{2}\right) *$ localisation in the tissues of pearl millet, sorghum and french bean seedlings inoculated with Sclerospora graminicola

\begin{tabular}{|c|c|c|c|c|c|c|c|c|c|c|c|}
\hline \multirow{4}{*}{$\begin{array}{l}\text { Test seedling } \\
\text { Highly resistant pearl } \\
\text { millet (IP18293) - Host }\end{array}$} & \multirow{3}{*}{$\begin{array}{l}\text { Time } \\
\text { (hai) }\end{array}$} & \multicolumn{10}{|c|}{$\%$ Cells stained / category ${ }^{1}$ of staining in the region } \\
\hline & & \multicolumn{5}{|c|}{ with HR } & \multicolumn{5}{|c|}{ without HR } \\
\hline & & 0 & 1 & 2 & 3 & 4 & 0 & 1 & 2 & 3 & 4 \\
\hline & 4 & 57 & 10 & 15 & 11 & 7 & 69 & 17 & 10 & 4 & 0 \\
\hline & 8 & 39 & 11 & 19 & 19 & 12 & 58 & 24 & 14 & 4 & 0 \\
\hline & 12 & 26 & 15 & 10 & 20 & 29 & 35 & 28 & 28 & 7 & 2 \\
\hline & 24 & 9 & 0 & 0 & 32 & 59 & 17 & 20 & 50 & 9 & 4 \\
\hline \multirow{4}{*}{$\begin{array}{l}\text { Induced resistant } \\
\text { pearl millet (HB3 treated } \\
\text { with } 2 \% \text { leaf extract of } \\
\text { D. metel) - Host }\end{array}$} & 4 & 66 & 5 & 10 & 19 & 0 & 71 & 12 & 17 & 0 & 0 \\
\hline & 8 & 48 & 9 & 14 & 20 & 9 & 57 & 15 & 24 & 4 & 0 \\
\hline & 12 & 35 & 10 & 19 & 19 & 17 & 40 & 22 & 25 & 12 & 1 \\
\hline & 24 & 14 & 3 & 19 & 30 & 34 & 21 & 33 & 35 & 7 & 4 \\
\hline \multirow{4}{*}{$\begin{array}{l}\text { Susceptible pearl millet } \\
\text { (HB3) - Host }\end{array}$} & 4 & 100 & 0 & 0 & 0 & 0 & 89 & 4 & 7 & 0 & 0 \\
\hline & 8 & 56 & 9 & 11 & 14 & 10 & 71 & 12 & 17 & 0 & 0 \\
\hline & 12 & 43 & 7 & 17 & 17 & 16 & 54 & 16 & 25 & 5 & 0 \\
\hline & 24 & 25 & 10 & 12 & 17 & 36 & 35 & 23 & 32 & 7 & 3 \\
\hline \multirow{4}{*}{$\begin{array}{l}\text { Sorghum (SGMN 10/8) - } \\
\text { Non-host }\end{array}$} & 4 & 100 & 0 & 0 & 0 & 0 & 95 & 1 & 4 & 0 & 0 \\
\hline & 8 & 100 & 0 & 0 & 0 & 0 & 81 & 8 & 11 & 0 & 0 \\
\hline & 12 & 53 & 12 & 10 & 17 & 8 & 57 & 10 & 25 & 8 & 0 \\
\hline & 24 & 47 & 3 & 7 & 24 & 19 & 51 & 7 & 31 & 7 & 4 \\
\hline \multirow{4}{*}{$\begin{array}{l}\text { French bean (S9) - Non- } \\
\text { host }\end{array}$} & 4 & 100 & 0 & 0 & 0 & 0 & 93 & 3 & 4 & 0 & 0 \\
\hline & 8 & 100 & 0 & 0 & 0 & 0 & 79 & 7 & 10 & 4 & 0 \\
\hline & 12 & 51 & 8 & 20 & 11 & 10 & 68 & 17 & 10 & 5 & 0 \\
\hline & 24 & 44 & 10 & 21 & 14 & 11 & 53 & 14 & 25 & 8 & 0 \\
\hline
\end{tabular}

* Average of three independent experiments each with three replicates of 10 seedlings each. hai - hours after inoculation

${ }^{1} 0$ - no localisation; 1 - light and patchy localisation; 2 - light and confluent localisation; 3 - dark and patchy localisation; 4 - dark and confluent localisation

mildew disease management in the susceptible HB3 cultivar of pearl millet using leaf $D$. metel extract support the above reports. Since both the non-hosts did not record any downy mildew symptoms, they were designated as immune to the downy mildew pathogen.

HR has been associated with resistance responses in interactions between plants and oomycetes in general and to genetic resistance to Phytophthora and downy mildew oomycetes in particular (Dangl et al., 1996; Kamoun et al., 1999; Vleeshouwers et al., 2000). Rapid expression of HR in the highly resistant and induced resistant pearl millet seedlings and its delayed expression in the non-hosts recorded in the present study are in accordance with the suggestion that HR and HR-related pathways are more important in resistance against host-specific biotrophic pathogens such as downy mildew. Difference in the rapidity and degree of HR as a response to inoculation with $S$. graminicola observed in the present study could be due to variation of expression of a resistance gene. Such variation depending on the interacting pathogen and plant genotype has been reported earlier (Kamoun et al.,
1999).

It is known that during HR recognition of pathogen by the host induces a co-ordinated series of morphological and biochemical changes that culminate in cell death resulting in a zone of dead cells around the site of attempted penetration (Milosevic \& Slusarenko, 1996). In the present study, rapid and intense cell death observed in the resistant and induced resistant pearl millet seedlings probably leads to restricted pathogen development resulting in their resistant reaction to downy mildew. It is widely speculated that the benefit of HR cell death is its ability to halt the spread of fungal hyphae and to kill the fungus in the process (Richael \& Gilchrist, 1999). Cell death associated with the limitation of pathogen spread has been observed in many incompatible plant-pathogen interactions (Milosevic \& Slusarenko, 1996; Rusterucci et al., 1996; Heath, 1999). Delayed and a lesser degree of cell death observed in the non-hosts sorghum and french bean in the present study are in accordance with reports that in the non-hosts, pathogen restriction has been achieved in spite of restricted cell death (Mittler et al., 1995; Greenberg, 1997). 
It is reported that $\mathrm{H}_{2} \mathrm{O}_{2}$ from the oxidative burst acts as a trigger for cell death (Mehdy, 1994; Tenhaken et al., 1995) which also makes it a source of signal molecules (Greenberg, 1997). When the total number of cells showing $\mathrm{H}_{2} \mathrm{O}_{2}$ localisation in each test seedling were considered, it was observed that the number of cells localised in the region with HR were greater than the cells localised in the region without HR. When the amount of $\mathrm{H}_{2} \mathrm{O}_{2}$ localised reached a threshold quantity, cell death occurred, which was further manifested as dark brown necrotic spots. Hence, visual appearance of HR was observed only after $\mathrm{H}_{2} \mathrm{O}_{2}$ localisation occurred. When the $\mathrm{H}_{2} \mathrm{O}_{2}$ accumulated in the cells were quantified, it was observed that although cells showing light localisation were more in the region without HR, it did not contribute to the visual appearance as the threshold quantity of $\mathrm{H}_{2} \mathrm{O}_{2}$ had not accumulated. But, when the darkly stained cells were considered, it was clearly observed that there occurred a demarcating difference in the number of cells darkly stained in the regions with HR and without HR. This also showed that the darkly localised cells contained the threshold quantity of $\mathrm{H}_{2} \mathrm{O}_{2}$ that contributed to the visual appearance of HR. Occurrence of cell death as a result of $\mathrm{H}_{2} \mathrm{O}_{2}$ accumulation and requirement of a threshold quantity of $\mathrm{H}_{2} \mathrm{O}$, for occurrence of cell death has been reported (Tenhaken et al., 1995; Greenberg, 1997).

\section{Acknowledgements}

This work has been carried out in the project on "Systemic Acquired Resistance" funded by Danish International Development Agency under the Enhancement of Research Capacity Programme (DANIDA-ENRECA), Denmark. We are grateful to Prof. Smedegaard-Petersen, the Principal Responsible Party of the DANIDA-ENRECA project for the financial assistance. The facilities provided by the Indian Council of Agricultural Research (ICAR), Government of India, New Delhi, through the All India Coordinated Pearl Millet Improvement Programme (AICPMIP) is also gratefully acknowledged.

\section{References}

Bestwick C S, Brown I R, Bennett M H R, Mansfield J W. 1997. Localisation of hydrogen peroxide accumulation during the hypersensitive reaction of lettuce cells to Pseudomonas syringae pv. phaseolicola. Plant Cell 9:209-221.

Dangl J L, Dietrich R A, Richberg M H. 1996. Death don't have mercy: Cell death programs in plant-microbe interactions. Plant Cell 8:1793-1807.

Geetha S, Shetty S A, Shetty H S, Prakash H S. 1998. Sclerospora graminicola and arachidonic acid-induced autofluorescence in downy mildew resistant and susceptible genotypes of pearl millet. Annals of Applied Biology 133:136139.
Greenberg J T. 1997. Programmed cell death in plant-pathogen interactions. Annual Review of Plant Physiology and Plant Molecular Biology 48:525-545.

Harding S A, Roberts D M. 1998. Incompatible pathogen infection results in enhanced reactive oxygen and cell death responses in transgenic tobacco expressing a hyperactive mutant calmodulin. Planta 206:253-258.

Heath M C. 1999. The enigmatic hypersensitive response: induction, execution, and role. Physiological and Molecular Plant Pathology 55:1-3.

Huckelhoven R, Fodor J, Preis C, Kogel K-H. 1999. Hypersensitive cell death and papilla formation in barley attacked by the powdery mildew fungus are associated with hydrogen peroxide but not with salicylic acid accumulation. Plant Physiology 119:1251-1260.

Kamoun S, Huitema E, Vleeshouwers V G A A. 1999. Resistance to oomycetes: a general role for the hypersensitive response? Trends in Plant Sciences 4:196-200.

Konstantinidou-Deltsinis S, Schmitt A. 1998. Impact of treatment with plant extracts from Reynoutria sachalinensis (F. Schmidt) Nakai. on intensity of powdery mildew severity and yield in cucumber under high disease pressure. Crop Protection 17:649-656.

Kumar V U, Meera M S, Hindumathy C K, Shetty H S. 1993. Induced systemic resistance protects pearl millet plants against downy mildew disease due to Sclerospora graminicola. Crop Protection 12:458-462.

Kumar V U, Hindumathy C K, Kini K R, Shetty H S. 1998. Prior inoculation inducing resistance to downy mildew (Sclerospora graminicola) enhances growth, peroxidase and $\beta$-1,3-glucanase activity in pearl millet (Pennisetum glaucum). Journal of Plant Pathology 80:203-209.

Lamb C J, Dixon RA. 1997. The oxidative burst in plant disease resistance. Annual Review of Plant Physiology and Plant Molecular Biology 48: 251-275.

Marty-Teysset C, Torre F de la, Garell J-R. 2000. Increased production of hydrogen peroxide by Lactobacillus delbruckii subsp. bulgaricus upon aeration: Involvement of an NADH oxidase in oxidative stress. Applied and Environmental Microbiology 66:262-267.

Mehdy M C. 1994. Active oxygen species in plant defense against pathogens. Plant Physiology 105:467-472.

Milosevic N, Slusarenko AJ. 1996. Active oxygen metabolism and lignification in the hypersensitive response in bean. Physiological and Molecular Plant Pathology 49:143-158.

Mittler R, Shulaev V, Lam S. 1995. Coordinated activation of programmed cell death and defense mechanisms in transgenic tobacco plants expressing a bacterial proton pump. The Plant Cell 7:29-42.

Nagarathna K C, Shetty SA, Shetty H S. 1993. Hypersensitive reaction in Pennisetum glaucum and associated changes in defense-related enzymes in response to infection by Sclerospora graminicola. 6th International Congress on Plant Pathology, Montreal, Canada, $231 \mathrm{pp}$.

O'Connell R J, Bailey J A, Richmond D V. 1985. Cytology and physiology of infection of Phaseolus vulgaris by Colletotrichum lindemuthianum. Physiological Plant Pathology 27:75-98.

Olson P D, Varner J E. 1993. Hydrogen peroxide and lignification. The Plant Journal 4:887-892.

Richael C, Gilchrist D. 1999. The hypersensitive response: A case of hold or fold? Physiological and Molecular Plant Pathology 55:5-12.

Rusterucci C, Stallart V, Milat M-L, Pugin A, Ricci P, Blein J-P. 1996. Relationship between active oxygen species, lipid peroxidation, necrosis and phytoalexin production induced by elicitins in Nicotiana. Plant Physiology 111:885-891.

Safeeulla K M. 1976. Biology and control of the downy mildews of pearl millet, sorghum and finger millet. Mysore: Wesley Press, 304 pp. 
Shailasree S, Sarosh B R, Vasanthi N S, Shetty H S. 2001. Seed treatment with $\beta$-amino-n-butyric acid protects Pennisetum glaucum systemically from Sclerospora graminicola. Pest Management Science 57:1-8.

Schulze-Lefert P, Vogel J. 2000. Closing the ranks to attack by powdery mildew. Trends in Plant Sciences 5:343-348.

Shivakumar P D. 2000. Induction of systemic resistance in pearl millet against downy mildew disease and the mechanism of resistance. Ph.D. Thesis, University of Mysore, $142 \mathrm{pp}$.

Singh U P, Prithviraj B. 1997. Neemazal, a product of neem (Azadirachta indica), induces resistance in pea (Pisum sativum) against Erysiphe pisi. Physiological and Molecular Plant Pathology 51:181-194.

Tenhaken R, Levine A, Brisson L F, Dixon R A, Lamb C J. 1995. Function of the oxidative burst in hypersensitive disease resistance. Proceedings of National Academy of Sciences USA 92:4158-4163.
Thordal-Christensen H, Zhang Z, Wei Y, Collinge D B. 1997. Sub-cellular localization of $\mathrm{H}_{2} \mathrm{O}_{2}$ accumulation in papillae and hypersensitive response during the barley - powdery mildew interaction. The Plant Journal 11:1187-1194.

Vleeshouwers V G A A, van Dooijeweert W, Govers F, Kamoun S, Colon L T. 2000. The hypersensitive response is associated with host and nonhost resistance to Phytophthora infestans. Planta 210:853-864.

Wilson C L, Solar J M, Ghaouth A E, Wisniewski M R. 1997. Rapid evaluation of plant extracts and essential oils for antifungal activity against Botrytis cinerea. Plant Disease 81:204-210. 
